\title{
Preliminary phytochemical studies for the quantification of secondary metabolites of medicinal importance in the plant, Acalypha fruticosa Forssk
}

\author{
A. M. Anandakumar, S. Paulsamy*, P. Sathish kumar and P. Senthilkumar \\ PG and Research Department of Botany, Kongunadu Arts and Science College, Coimbatore-641029, INDIA \\ *Corresponding author. E-mail: paulsami@yahoo.com
}

\begin{abstract}
The medicinal plant, Acalypha fruticosa Forssk for the treatment of dyspepsia, stomachache, fever, jaundice, skin diseases and even as an antidote is generally distributed in different environments of tropical region in Coimbatore district of Tamil Nadu. However, its occurrence is more common in lower hills of Western Ghats and other habitats in this region where the soil is stony with low moisture. So far, there was no study on the influence of habitat conditions on the change in the content of secondary metabolites of medicinal importance in this plant. Hence to know the changes in the content of such secondary metabolites in the leaves of $A$. fruticosa, the present study was undertaken in three different habitats. Thin layer chromatography revealed the presence of phytochemical compounds viz., alkaloids, flavonoids and saponins in the leaves of all the three populations. Further the content of all these compounds are found to be higher in the population of dry habitats.
\end{abstract}

Keywords: Medicinal plant, Dyspepsia, Secondary metabolites

\section{INTRODUCTION}

The use of plant, plant extract or plant derived chemicals to treat disease is therapeutic modality which has stood the test of time. (Anwannil and Alta, 2005). Early human recognized their dependence on nature in both health and illness. Led by instinct test and experience, primitive people treated illness by using plant, animal parts and minerals that were not part of their usual diet.

For a long period of time, plants have been a valuable source of natural products for maintaining human health. According to World Health Organization medicinal plants would be the best source to obtain a variety of drugs. About $80 \%$ of individuals from developed countries use traditional medicine, which has compounds derived from medicinal plants. Therefore, such plants should be investigated to better understand their properties, safety and efficiency (Ellof, 1998).

Among the large number of medicinal plants, many species of Acalypha are found to have diverse phytochemical compounds of medicinal properties (Sofowora, 1982 Duraipandiyan, et al., 2006; and Mothana et al., 2008). The species, Acalypha fruticosa is an erect shrub, woody, $3.5 \mathrm{~m}$ in height with yellow resinous glands on the lower surface. The species appeared to be present up to $1800 \mathrm{~m}$ in southern Western Ghats (Gamble, 1958). Locally the plant was used as vegetable and having curative effect on cholera, sexually transmitted diseases, stomach problems and whooping cough and relieves fever and cold. Stems are used for local uses like to build fences, weaving granaries and local doors in rural areas of Coimbatore. For these multiple values, this species is overexploited extensively in Coimbatore district, Tamil Nadu in recent times. It occurs principally on hill slopes and has an important role in protecting the integrity of slopes. Owing to its wider ecological amplitude, the studies on the influence of varied habitats on the production of phytochemicals are more important to know the suitable habitat for cultivation. Hence in the present study, population of $A$. fruticosa in three different habitats have been taken to determine the impact of environment on the production of certain secondary metabolites of medicinal importance.

\section{MATERIALS AND METHODS}

Plant material : The leaves of the plant material of $A$. fruticosa used in the present investigation were collected from three different vegetations viz., dry deciduous forest at Maruthamalai in Western Ghats, scrub jungles at Chennimalai of the Eastern Ghats and evergreen forests of Burliar at Nilgiris the Western Ghats and dried under shade condition. Ten grams of leaf powder was added with $100 \mathrm{ml}$ of the solvents viz., chloroform and methanol separately and kept in shaker for $24 \mathrm{hrs}$. The extract was filtered and stored in cool place for further studies. 


\section{Phytochemical analysis}

Thin layer chromatography (TLC) : The preliminary phytochemical studies were performed by following the method of Wagner et al. (1984) by using silica gel-G thin layer chromatographic plate of $15 \times 5 \mathrm{~cm}$ with $3 \mathrm{~mm}$ thickness.

For the separation of phytochemical compounds, chloroform and methanolic extracts of leaves of A. fruticosa were spotted manually using capillary tube. The spotted plates were put in a solvent chamber which contained various solvent systems to detect the suitable mobile phase as per the methods of Wagner and Bladt (1984). After the separation of phytochemicals, various spray reagents such as dragondorff's reagent, natural product reagent and vanillin sulphuric reagent were used to identify the compounds. The colour of the spots was noted and the $R_{f}$ values were calculated by using the following formula:

Distance traveled by the drug

Retention factor $\left(R_{f}\right)=\longrightarrow \mathrm{X} 100$

Distance traveled by the solvent

The quantitative phytochemical studies were carried out by following the method of Horborne (1973) and Trease and Evans (1985). Triplicate samples were maintained for all experiments.

\section{RESULTS AND DISCUSSION}

The TLC studies showed that the chloroform and methanol extracts of leaf of the species, A. fruticosa

Table 1. Determination of secondary metabolites with suitable mobile phase through thin layer chromatography in the leaves of Acalypha fruticosa.

\begin{tabular}{|c|c|c|c|c|c|}
\hline Extract & Mobile phase & Spray Reagent & $\begin{array}{l}\text { Colour of the } \\
\text { spot/ band }\end{array}$ & $R_{f}$ Value $(\%)$ & Compound \\
\hline \multirow{7}{*}{ Chloroform } & Ethyl acetate: $\mathrm{MeoH}: \mathrm{H}_{2} \mathrm{O}$ & \multirow{3}{*}{$\begin{array}{l}\text { Dragendorff } \\
\text { reagent }\end{array}$} & & & \\
\hline & $90: 8.5: 5$ & & Brownish spot & 57.12 & Alkaloids \\
\hline & $\begin{array}{c}\text { Chloroform:MeoH } \\
80: 15 \\
\end{array}$ & & Orange & 80.40 & Alkaloids \\
\hline & $\begin{array}{c}\text { Chloroform: Ethyl } \\
\text { acetate } \\
50: 50\end{array}$ & \multirow{2}{*}{$\begin{array}{l}\text { Natural } \\
\text { products } \\
\text { reagent }\end{array}$} & Yellowish zone & 68.84 & Flavonoids \\
\hline & $\begin{array}{c}\text { N-Butanol:Glacial acetic } \\
\text { acid: } \mathrm{H}_{2} \mathrm{O} \\
45: 15: 40\end{array}$ & & $\begin{array}{l}\text { Florescent (UV- } \\
365)\end{array}$ & 54.12 & Flavonoids \\
\hline & $\begin{array}{c}\text { Ethyl } \\
\text { acetate:MeoH:Ethanol: } \\
\mathrm{H}_{2} \mathrm{O} \\
80: 10: 4: 8\end{array}$ & $\begin{array}{l}\text { Without } \\
\text { chemical } \\
\text { reagent }\end{array}$ & $\begin{array}{l}\text { Distinct band } \\
\text { formation }\end{array}$ & 80.98 & Glycosides \\
\hline & $\begin{array}{l}\text { Chloroform:MeoH } \\
80: 20\end{array}$ & $\begin{array}{l}\text { Vanillin } \\
\text { sulphuric acid } \\
\text { reagent }\end{array}$ & Violet blue & 96.07 & Saponins \\
\hline \multirow{7}{*}{$\begin{array}{l}\text { Methanol } \\
(\mathrm{MeoH})\end{array}$} & Ethyl acetate: $\mathrm{MeoH}: \mathrm{H}_{2} \mathrm{O}$ & \multirow{3}{*}{$\begin{array}{l}\text { Dragendorff } \\
\text { reagent }\end{array}$} & & & \\
\hline & $95: 8.5: 5$ & & Orange & 48.40 & Alkaloids \\
\hline & $\begin{array}{c}\text { Chloroform:MeoH } \\
\text { 80:15 }\end{array}$ & & Orange & 85.48 & Alkaloids \\
\hline & $\begin{array}{c}\text { Chloroform: Ethyl } \\
\text { acetate } \\
55: 40\end{array}$ & \multirow{2}{*}{$\begin{array}{l}\text { Natural } \\
\text { products } \\
\text { reagent }\end{array}$} & \multirow[b]{2}{*}{$\begin{array}{l}\text { Florescent (UV- } \\
365)\end{array}$} & 65.84 & Flavonoid \\
\hline & $\begin{array}{c}\text { N-Butanol:Glacial acetic } \\
\text { acid: } \mathrm{H}_{2} \mathrm{O} \\
40: 11: 50 \\
\end{array}$ & & & 61.40 & Flavonoid \\
\hline & $\begin{array}{c}\text { Ethyl } \\
\text { acetate:MeoH:Ethanol:H } \\
{ }_{2} \mathrm{O} \\
80: 10: 4: 8\end{array}$ & $\begin{array}{l}\text { Without } \\
\text { chemical } \\
\text { reagent }\end{array}$ & $\begin{array}{l}\text { Distinct band } \\
\text { formation }\end{array}$ & 93.46 & Glycosides \\
\hline & $\begin{array}{c}\text { N-Butanol:Glacial acetic } \\
\text { acid: } \mathrm{H}_{2} \mathrm{O} \\
45: 10: 40 \\
\text { Chloroform:MeoH } \\
80: 10\end{array}$ & $\begin{array}{l}\text { Vanillin } \\
\text { sulphuric acid } \\
\text { reagent }\end{array}$ & Violet blue & 90.80 & Saponins \\
\hline
\end{tabular}


contains the secondary metabolites of medicinal importance viz., alkaloids, flavonoids, glycosides and saponins (Table-1). Sofowora (1993) reported that the presence of secondary metabolites like alkaloids, flavonoids, steroids, glycosides, saponins etc., in plants is the basic character for their medicinal properties. The presence of all these compounds justifies the medicinal usage of this species by the local people of Coimbatore in adequate quantities. In addition, among the three environments analyzed, the stress conditions as in the deciduous forests of Maruthamalai hills in Western Ghats and scrub jungles of Chennimalai hills in Eastern Ghats in western Tamil Nadu are more suitable for the cultivation of the species, A. fruticosa in terms of higher medicinal properties. However, further studies are suggested to purify the active compounds to formulate the new drugs.

Table 2. Quantitative estimation of secondary metabolites in the leaves of populations of three different habitats of Acalypha fruticosa.

\begin{tabular}{cccc}
\hline \multirow{2}{*}{$\begin{array}{c}\text { Compounds } \\
(\mathrm{mg} / \mathrm{g})\end{array}$} & $\begin{array}{c}\text { Maruthamalai } \\
\text { (deciduous forest) }\end{array}$ & $\begin{array}{c}\text { Chennimalai } \\
(\text { dry deciduous forest) }\end{array}$ & Burliar (evergreen forest) \\
\cline { 2 - 4 } Alkaloids & $2.80^{\mathrm{a}} \pm 0.23$ & $4.00^{\mathrm{b}} \pm 0.35$ & $1.70^{\mathrm{c}} \pm 0.13$ \\
Flavanoids & $9.77^{\mathrm{a}} \pm 0.80$ & $10.50^{\mathrm{b}} \pm 0.81$ & $8.20^{\mathrm{c}} \pm 0.71$ \\
Glycosides & $1.80^{\mathrm{a}} \pm 0.13$ & $2.00^{\mathrm{a}} \pm 0.14$ & $1.20^{\mathrm{b}} \pm 0.10$ \\
Saponins & $2.00^{\mathrm{a}} \pm 0.16$ & $6.00^{\mathrm{b}} \pm 0.57$ & $1.60^{\mathrm{a}} \pm 0.12$ \\
\hline
\end{tabular}

The values of horizontal rows followed by different letter are significantly different at 5\% level according to DMRT.

district for various ailments. Suitable mobile phases at appropriate proportion have been determined separately for the chloroform and methanol extracts of leaf of $A$. fruticosa in the present study (Table 1). Mostly the alcoholic solvents have been determined to be the more suitable mobile phases for the separation of secondary metabolites in the leaves of $A$. fruticosa.

The results of the gravimetric and spectrophotometric studies report that the quantity of secondary metabolites identified (alkaloids, flavonoids, glycosides and saponins) was varied widely across the three populations of $A$. fruticosa studied (Table 2). The leaves of populations of A. fruticosa in all the three habitats contained significantly higher flavonoids $(8.2 \mathrm{mg} / \mathrm{g}$ in the evergreen forest at Burliar $-10.5 \mathrm{mg} / \mathrm{g}$ in the scrub jungle at Chennimalai) than the other secondary metabolites estimated. Alan and Miller (1996) explained that the plant species of higher flavonoid content naturally have antibacterial, antiinflammatory, antiallergic, antiviral, antineoplastic, antithrombotic and vasodilatory activities. This fact further supports the existing medicinal value of $A$. fruticosa in the rural areas of Coimbatore district. The study further reports that the populations of A. fruticosa in water stress condition (deciduous forest in Maruthamalai and scrub jungle in Chennimalai) hold higher content of all the secondary metabolites identified than that of the populations in humid area (evergreen forest in Burliar) (Table 2). It is of common fact that the production of secondary metabolites is higher in the plants of stress habitats to resist the unfavorable environmental conditions (Trease and Evans, 1985; Maranz and Wiesman, 2004).

The study confirmed the therapeutic value of A. fruticosa and further its folklore medicinal value is proved by the presence of secondary metabolites of medicinal importance

\section{REFERENCES}

Alan, L. and Miller, N.D.(1996). Antioxidant flavonoids: Function and Clinical Usage. Alt. Med. Rev. 1 (2): 109-111.

Anwannil, H.G. and Alta, R.(2005). Trends in ethnopharmocology. J. Ethnopharmacol. 100: 43-49.

Duraipandiyan, V., Ayyanar, M. and Ignacimuthu, S. (2006). Antimicrobial activity of some ethnomedicinal plants used by puliyar tribe from Tamil Nadu, India. BMC Complement. Altern. Med. 20: 6-35.

Ellof, J.N. (1998). Which extractant should be used for the screening and isolation of antimicrobial components from plants? J. Ethnopharmacol. 60:1-6.

Gamble, J.S. and Fischer, C.(1958). The flora of Presidency of Madras. Bishen Singh Mahendra Pal Singh, Dehradun 3:13291331.

Horborne, J.B. (1998). Phytochemical methods, a guide to modern techniques of plant analysis. Springer (India) Private Limited, New Delhi.

Maranz, S. and Wiesman, Z. (2004). Effect of climate on tocopherols in shea butter. J. of Agri. and Food Chemis. 52: 2934-2937.

Mothana, R.A., Abdo, S.A., Hasson, S., Althawab, F.M., Alaghbari, A. A. and Lindequist, U. (2008). Antimicrobial, antioxidant and cytotoxic activities and phytochemical screening of some Yemeni medicinal plants. Eviden based complement. Altern. Med. 28: 4-4.

Sofowora, A. (1982). Medicinal plants and traditional medicine in Africa. $1^{\text {st }}$ Edn. New York.: John Wiley and Sons, pp: 256.

Sofowora, L.A. (1993). Medicinal plant and traditional medicine in Africa. Ibaban: Spectrum Books Ltd., pp: 55-71.

Trease, G.E. and Evans, W.C. (1985). Pharmacognosy. Billiere: English Language Book Society,. 12: 81-628.

Wagner, H., Bladt, S. and Zgainski, E.M. (1984). Plant drug analysis - A Thin Layer Chromatography Atlas. SpringerVerlag, Berlin. 